Published every April, August and December

JURNAL RISET AKUNTANSI \& KEUANGAN

ISSN:2541-061X (Online). ISSN:2338-1507(Print). http://ejournal.upi.edu/index.php/JRAK

\title{
Analisis Kinerja Reksadana Syariah
}

\author{
Winda Waridah ${ }^{1}$, Elis Mediawati ${ }^{2}$ \\ Program Studi Akuntansi, FPEB, Universitas Pendidikan Indonesia. Bandung
}

\begin{abstract}
This study aims to determine the performance of Islamic Mutual Funds in Indonesia, especially Mutual stocks type with the study period from 2010 to 2014. Method of performance measurement used is Sharpe Ratio. The data used in this study is secondary data with sample 6 Sharia Reksadana Shares with sampling technique using purposive sampling. The analysis technique used in this research is the descriptive technique with quantitative approach. The result of the research shows that Reksadana Cipta Syariah Equity is the Sharia Mutual Fund that has the best performance compared to other Sharia Reksadana Shares
\end{abstract}

Keyword: Sharia Funds Mutual Funds; Performance; Sharpe Ratio;.

\begin{abstract}
Abstrak. Penelitian ini bertujuan untuk mengetahui kinerja Reksadana Syariah di Indonesia khususnya Reksadana jenis saham dengan periode penelitian 2010- 2014. Metode pengukuran kinerja yang digunakan adalah Sharpe Ratio. Data yang digunakan dalam penelitian ini adalah data sekunder dengan sampel 6 Reksadana Saham Syariah dengan teknik pengambilan sampel menggunakan purposive sampling. Tehnik analisis yang digunakan dalam penelitian ini adalah teknik deskriptif dengan pendekatan kuantitatif. Hasil penelitian menunjukkan bahwa Reksadana Cipta Syariah Equity merupakan Reksadana Saham Syariah yang memiliki kinerja terbaik dibandingkan dengan Reksadana Saham Syariah lainnya

Kata Kunci: Reksadana Saham Syariah; Kinerja; Sharpe Ratio;
\end{abstract}

Corresponding author. Email. ${ }^{1}$ windawaridah@yahoo.co.id dan ${ }^{2}$ elis.mediawati@upi.edu. Jalan Setiabudi No.229, Isola, Sukasari, Kota Bandung, Jawa Barat 40154

How to cite this article. Winda Waridah, E. M. (2017). Analisis Kinerja Reksadana Syariah. Jurnal Riset Akuntansi Dan Keuangan Program Studi Akuntansi Fakultas Pendidikan Ekonomi Dan Bisnis Universitas $\begin{array}{lllll}\text { Pendidikan } \quad \text { Indonesia, } & \text { 4(2), } & \text { Retrieved } & \text { from }\end{array}$ http://ejournal.upi.edu/index.php/JRAK/article/view/4043

History of article. Received: Mei 2016, Revision: Juli 2016, Published: Agustus 2016

Online ISSN: 2541-061X.Print ISSN: 2338-1507. DOI: 10.17509/jrak.v4i2.4043

Copyright@2016. Jurnal Riset Akuntansi dan Keuangan Program Studi Akuntansi FPEB UPI 


\section{PENDAHULUAN}

Dewasa ini, semakin berkembangnya perekonomian dan keuangan Islam di Indonesia menjadi fenomena yang menggembirakan dan menyegarkan bagi masyarakat Indonesia yang mayoritas penduduknya muslim. Praktik kegiatan ekonomi konvensional, khususnya dalam kegiatan pasar modal yang mengandung unsur spekulasi sebagai salah satu komponennya nampaknya masih menjadi hambatan psikologis bagi umat Islam untuk turut aktif dalam kegiatan investasi di pasar modal. Perkembangan pasar modal di Indonesia menjadi daya tarik tersendiri bagi investor untuk menanamkan modalnya di bursa. Namun untuk dapat berinvestasi secara langsung, ada beberapa kendala yang dihadapi oleh para investor seperti keterbatasan pengetahuan, informasi dan waktu. Salah satu alternatif instrumen investasi yang dapat menjadi solusi atas kendala tersebut yakni reksadana.

Reksadana ini merupakan salah satu strategi diversifikasi dalam berinvestasi dan merupakan alternatif investasi bagi masyarakat pemodal, khususnya pemodal kecil dan pemodal yang tidak memiliki banyak waktu dan keahlian untuk menghitung return dan risiko atas investasi mereka. Hadirnya Reksadana Syariah sejak tahun 1997 di Indonesia melengkapi keragaman Reksadana Konvensional yang telah ada sebelumnya untuk menjadi pilihan investasi bagi para investor, tidak hanya investor muslim saja tetapi investor secara umum. Sebagai salah satu instrumen investasi, reksadana syariah memiliki kriteria yang berbeda dengan reksadana konvensional pada umumnya. Perbedaan ini terletak pada pemilihan instrumen investasi dan mekanisme investasi yang tidak boleh bertentangan dengan prinsip- prinsip syariah. Perbedaan lainnya

adalah keseluruhan proses manajmen portofolio dilakukan screening (penyaringan) dan cleansing (pembersihan) dari aspek nonhalal.

Reksadana Syariah di Indoensia selama 5 (lima) tahun terakhir ini yakni mulai tahun 2010 sampai dengan 2014 menunjukkan tingkat kinerja dan perkembangan yang positif. Hal tersebut bisa dilihat dari jumlah reksadana yang terus bertambah serta dana kelolaan yang semakin meningkat selama lima tahun terakhir ini, seperti yang terlihat pada grafik di bawah ini:

Grafik Perkembangan Jumlah Reksadana Syariah di Indonesia (2010 - 2014)

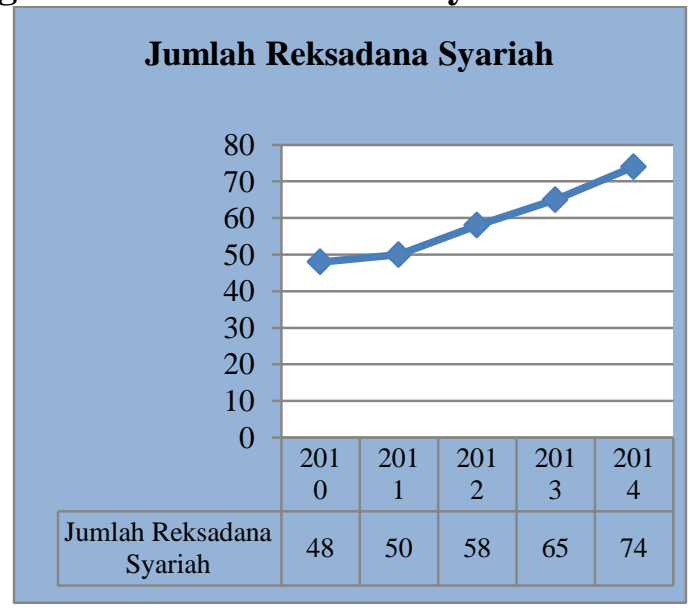

Sumber: Otoritas Jasa Keuangan (2014)

Gambar di atas menunjukkan perkembangan reksadana di Indonesia mulai tahun 2010 sampai dengan tahun 2014, di mana Reksadana Syariah setiap tahunnya menunjukkan trend yang positif dari segi jumlah reksadana yang beredar. Selain dari jumlah reksadana yang selalu bertambah setiap tahunnya, kinerja reksadana juga dapat 
dilihat dari Nilai Aktiva Bersih (NAB)- nya. Nilai Aktiva Bersih (NAB) merupakan nilai pasar wajar (fair market value) suatu efek dan kekayaan dari reksadana dikurangi dengan kewajiban. NAB ini merupakan salah satu tolak ukur dalam memantau hasil dari suatu reksadana.

Grafik Perkembangan NAB Reksadana Syariah (Periode 2010- 2014)

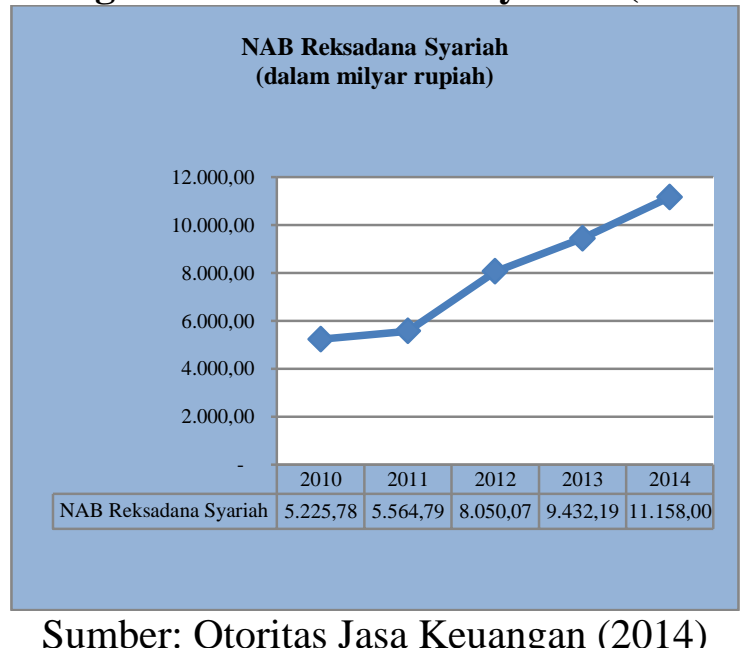

Gambar di atas menggambarkan besarnya dana kelolaan atau Nilai Aktiva Bersih (NAB) selama lima tahun terakhir dari Reksadana Syariah. Pertumbuhan NAB Reksadana Syariah selama 5 (lima) tahun mencapai $113,5 \%$ yaitu dari Rp 5,23 triliun tumbuh menjadi $\mathrm{Rp}$ 11,16 triliun, di mana peningkatan NAB Reksadana Syariah terbesar terjadi pada tahun 2012, yaitu sebesar $44,66 \%$ dari tahun sebelumnya.

Menurut Muliaman D. Hadad (2014: 22) yang merupakan Ketua Otoritas Jasa Keuangan, di samping industri keuangan konvensional, industri keuangan syariah di Indonesia memiliki potensi yang sangat besar untuk berkembang karena masih terbatasnya pangsa pasar industri keuangan syariah di Indonesia dibandingkan dengan industri keuangan konvensional. Selain dipicu oleh pertumbuhan ekonomi serta munculnya kesadaran masyarakat untuk berinvestasi, hal ini juga didorong oleh kondisi masyarakat Indonesia yang sebagian besar merupakan berstatus muslim, sehingga tidak hanya mempertimbangkan return semata tetapi juga mempertimbangkan prinsip yang tidak melanggar syariah dalam berinvestasinya.

Menurut Martalena \& Maya Malinda (2011: 85), berdasarkan portofolio asetnya reksadana diklasifikasikan menjadi Reksadana Pasar Uang, Reksadana Saham, Reksadana Pendapatan Tetap dan Reksadana Campuran. Berikut tabel yang menggambarkan perkemabangan NAB Reksadana di Indonesia berdasarkan alokasi assetnya:

Tabel 1. Perkembangan NAB Reksadana Syariah Berdasarkan Portofolio Assetnya

\begin{tabular}{|c|c|c|}
\hline No. & Jenis Reksadana & $\begin{array}{c}\text { NAB Reksadana Syariah (dalam triliun rupiah) } \\
\text { per November } 2014\end{array}$ \\
\hline 1. & Pasar Uang & 0,36 \\
\hline 2. & Saham & 6,14 \\
\hline 3. & Pendapatan Tetap & 0,39 \\
\hline 4. & Campuran & 1,64 \\
\hline
\end{tabular}

Sumber: Otoritas Jasa Keuangan: 2014 
Tabel di atas menunjukkan fenomena bahwa diantara jenis Reksadana yang ada berdasarkan alokasi assetnya, Reksadana Saham lebih unggul dibanding dengan jenis reksadana yang lainnya dengan nilai NAB paling tinggi yakni sebesar Rp 6,14 triliun untuk Reksadana Syariah. Menurut Martalena \& Maya Malinda (2011: 85), Reksadana Saham merupakan reksadana yang melakukan investasi sekurang- kurangnya $80 \%$ dari aktivanya dalam bentuk efek bersifat ekuitas (saham), selain itu jenis reksadana ini memiliki risiko yang lebih tinggi dibandingkan jenis reksadana yang lainnya dikarenakan saham mempunyai kecenderungan selalu berfluktuasi.

Pada umumnya, investor akan memilih untuk menginvestasikan dananya dengan pertimbangan- pertimbangan finansial, yaitu mempertimbangkan imbal hasil (return) dan risiko (risk) semata. Akan tetapi, ada pula investor yang dalam kegiatan investasinya tidak semata- mata mempertimbangkan aspek finansial namun juga mempertimbangkan nilai- nilai yang dianutnya agar tidak bertentangan dengan prinsip yang dianutnya (Ida Syafrida dkk, 2014: 196). Pesatnya pertumbuhan instrumen reksadana syariah, masalah yang dihadapi oleh para investor maupun investor potensial adalah bagaimana memilih alternatif reksadana yang ada berdasarkan kinerja portofolio (Vince Ratnawati \& Ningrum K, 2012: 2). Oleh karena itu, pengukuran kinerja reksadana merupakan suatu hal yang penting untuk dilakukan. Dalam menghasilkan suatu kinerja investasi selalu ada faktor yang terlibat. Begitu juga dengan reksadana, informasi mengenai risiko menjadi penting dalam membandingkan kinerja investasi reksadana. Pengukuran kinerja dengan mempertimbangkan risiko memberikan informasi bagi investor tentang sejauh mana suatu hasil atau kinerja reksadana dikaitkan dengan risiko yang diambil untuk mencapai kinerja tersebut.

Menurut Eko Priyo dan Ubaidillah (2009) bahwa pengukuran kinerja harus menggunakan standarisasi pengukuran Internasional. Adapun metode yang digunakan pada penelitian ini yakni metode Sharpe Ratio yang termasuk ke dalam model pengukuran kinerja risk adjusted return. Metode Sharpe merupakan salah satu standar pengukuran kinerja reksadana secara Internasional yang dikembangkan oleh William F. Sharpe (1966) yang telah teruji. Secara umum model pengukuran kinerja metode Sharpe dapat diterapkan untuk semua jenis reksadana sehingga penggunaan metode ini dapat menggambarkan kemampuan manajer investasi dalam mengolah reksadana dari setiap unit risiko yang diambil. Selain itu, disebutkan dalam situs www.bareksa.com bahwa metode Sharpe ini merupakan salah satu metode yang paling banyak digunakan di Indonesia. Dalam ajang penghargaan reksadana terbaik 2013, penggunaan metode Sharpe salah satunya merupakan kriteria dalam menentukan reksadana terbaik tersebut (www.beritasatu.com)

Berdasarkan latar belakang di atas, maka penelitian ini menetapkan objek yang akan diteliti dikhususkan pada Reksadana Saham Syariah untuk periode 2010- 2014. Objek penelitian dipilih pada reksadana jenis saham karena reksadana jenis ini memiliki karakteristik tertentu di mana risiko yang dihadapi lebih tinggi dibandingkan dengan reksadana jenis lain selain kecenderungan masyarakat Indonesia yang ternyata lebih tinggi dan lebih tertarik untuk berinvestasi pada reksadana jenis saham. Periode 20102014 ini dipilih karena adanya relevansi informasi yang menunjukkan kondisi akhir dari perusahaan terkait. Pemilihan pengukuran kinerja Reksadana Syariah dikarenakan untuk mengetahui tentang kinerja beberapa Reksadana Saham Syariah yang ada. Oleh karena itu, berdasarkan uraian di atas, maka peneliti tertarik untuk melakukan penelitian dengan judul "Analisis Kinerja Reksadana Syariah di Indonesia (Studi pada Reksadana Jenis Saham Periode 2010- 2014)".

Nilai aktiva bersih (NAB) merupakan nilai pasar wajar (fair market value) suatu efek dan kekayaan lain dari reksadana dikurangi dengan kewajiban. NAB merupakan salah satu tolak ukur dalam memantau hasil dari suatu reksadana. NAB/ unit penyertaan 
adalah harga wajar dari portofolio suatu reksadana setelah dikurangi biaya operasional kemudian dibagi jumlah saham/ unit penyertaan yang telah beredar (dimiliki investor) pada saat tersebut (Nofie Iman, 2008: 128). Rumus untuk menghitung NAB adalah sebagai berikut:

$$
N A B=\frac{(\text { Jumlah Asset }- \text { Total Kewajiban })}{\text { Jumlah Unit Penyertaan }}
$$

Menurut Frank J. Fabozzi (2000: 799), Sharpe merupakan alat ukur dari rasio pengembalian atau risiko (reward/ ratio risk) yang dikembangkan oleh William F. Sharpe. Pengukuran dengan metode Sharpe didasarkan atas apa yang disebut dengan premium risiko (risk premium). Risk premium adalah perbedaan (selisih) antara rata- rata kinerja yang dihasilkan oleh reksadana dan rata- rata kinerja bebas risiko (Risk Free Asset). Indikasinya adalah semakin tinggi nilai rasio Sharpe, maka semakin baik kinerjanya. Pengukuran metode Sharpe dapat dirumuskan sebagai berikut:

Di mana:

$$
S p=E(R i-R f) / \sigma p
$$

Sp $=$ Sharpe index

$\mathrm{Ri}=$ Return portofolio $\mathrm{i}$ pada periode $\mathrm{t}$

$\mathrm{Rf}=$ Return risk-free rate untuk periode $\mathrm{t}$

$\sigma \mathrm{p}=$ Standar deviasi atau total risiko portofolio

Berdasarkan teori dan fenomena empiris tersebut memberikan pemahaman bahwa pengukuran kinerja suatu instrumen investasi seperti reksadana saham memang sangat diperlukan untuk membantu investor dalam memutuskan pilihan investasinya. Pemilihan metode pengukuran kinerja yang sering digunakan oleh peneliti lain yakni metode Sharpe. Berdasar uraian di atas, peneliti menyusun kerangka pemikiran sebagai berikut:

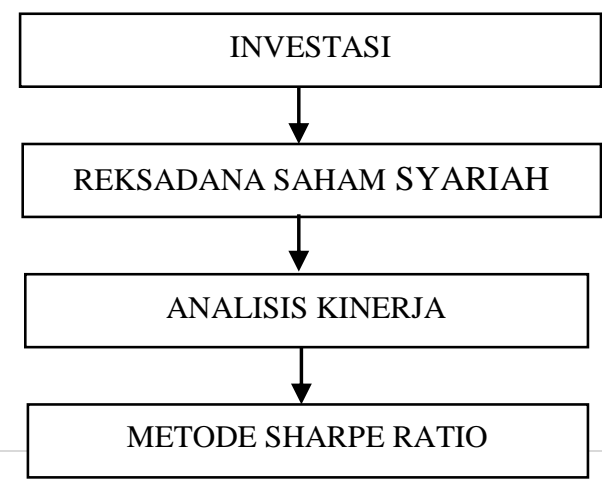

\section{METODOLOGI PENELITIAN}

Metode yang digunakan untuk menganalisis kinerja Reksadana Saham Syariah adalah metode deskriptif dengan pendekatan kuantitatif.

Variabel yang digunakan dalam penelitian ini adalah Sharpe Ratio, Return Reksadana Saham Syariah, Return Pasar sebagai benchmark, Excess Return, dan Standar Deviasi. Berikut adalah uraian dari dimensi yang digunakan dalam variabel:

Sharpe Ratio

$$
\begin{aligned}
& S p=E(R i-R f) / \sigma p \\
& \mathrm{Sp}=\text { Sharpe index } \\
& \mathrm{Ri}=\text { Return portofolio i pada } \\
& \text { periode } \mathrm{t} \\
& \mathrm{Rf}=\text { Return risk-free rate untuk } \\
& \text { periode } \mathrm{t} \\
& \sigma \mathrm{p} \quad=\text { Standar deviasi atau total } \\
& \text { risiko portofolio }
\end{aligned}
$$

Return Reksadana

Di mana:

$$
R_{R D}=\frac{N A B_{t}-N A B_{t-1}}{N A B_{t-1}}
$$

$\mathrm{R}_{\mathrm{RD}} \quad=$ Return Reksadana

$\mathrm{NABt}=$ Nilai Aktiva Bersih periode $\mathrm{t}$

$\mathrm{NAB}_{\mathrm{t}-1}=$ Nilai Akktiva Bersih periode sebelum $\mathrm{t}$

Return JII sebagai benchmark

Dimana:

$$
R_{m}=\frac{J I I_{t}-J I I_{t-1}}{J I I_{t-1}}
$$

$\mathrm{R}_{\mathrm{m}} \quad=$ Return pasar saham

JIIt $=$ Return pasar saham JII periode $\mathrm{t}$

$\mathrm{JII}_{\mathrm{t}-1}=$ Return pasar saham JII periode $\mathrm{t}-1$

\section{Excess Return}

Dimana:

$$
\text { Excess Return }=R_{r d}-R f
$$

$\mathrm{R}_{\mathrm{RD}}=$ Return Reksa Dana

$\mathrm{R}_{\mathrm{f}} \quad=$ Suku bunga bebas risiko 
Standar Deviasi

$$
\sigma=\frac{\sqrt{\sum\left(R_{R D}-E\left(R_{R D}\right)\right)^{2}}}{n-1}
$$

Di mana:

$\sigma=$ Standar deviasi return portofolio

$\mathrm{R}_{\mathrm{RD}}=$ Return reksadana periode $\mathrm{t}$

$\mathrm{E}=$ Expected return

$\mathrm{n} \quad=$ jumlah data

Populasi dalam penelitian ini adalah seluruh Reksadana yang listing di Otoritas Jasa Keuangan dan aktif selama periode penelitian 2010- 2014. Populasi reksadana yang masih aktif sampai tahun 2014 sebanyak 894 reksadana. Dari 894 Reksa Dana yang terdaftar di Bapepam-LK maka peneliti mengambil 166 Reksadana Saham yang terdaftar di Bapepam meliputi 24 Reksadana kategori Saham Syariah. . Dari populasi tersebut tidak semua populasi dijadikan sampel pada penelitian ini. Penarikan sampel penelitian dilakukan dengan metode purposive sampling yakni pemilihan sampel berdasarkan pada karakteristik tertentu yang dianggap mempunyai hubungan dengan karakteristik populasi yang sudah diketahuinya (Husein Umar, 2008: 92). Adapun kriteria penentuan sampel yang dipertimbangkan adalah sebagai berikut: (1) Reksadana saham adalah reksadana yang melakukan investasi sekurang-kurangnya $80 \%$ dari portofolio yang dikelolanya ke dalam efek bersifat ekuitas (saham). (2) Reksadana Saham Syariah yang dipilih adalah yang sudah dan tetap aktif serta tercatat di Bapepam selama periode penelitian 2010- 2014. (3) Kriteria untuk reksadana saham syariah yaitu, reksadana tidak termasuk dalam sektor-sektor yang berbasis suku bunga, seperti bank dan perusahaan pembiayaan, perusahaan rokok, serta hotel. (4) Reksadana Saham Syariah menyajikan Laporan Keuangan tahunan dari 2010- 2014 secara lengkap.

Berdasarkan kriteria tersebut, maka diambil 6 sampel Reksadana Saham Syariah sebagai berikut:

Tabel 2. Sampel Reksadana Saham Syariah

No. Manajer Investasi Reksadana Saham syariah

1. PT. PNM Investment Management PNM Ekuitas Syariah

2. PT. Batavia Prosperindo Aset Manajemen Batavia Dana Saham Syariah

3. PT. Trimegah Asset Management

Trim Syariah Saham

4. PT. Mandiri Manajemen Investasi

Mandiri Investa Atraktif Syariah

5. PT. Ciptadana Asset Management

Cipta Syariah Equity

6. PT. Manulife Aset Manajemen Indonesia

Manulife Syariah Sektoral Amanah

Jenis dan sumber data dalam penelitian ini adalah data sekunder, berasal dari data yang dipublikasikan dalam statistik atau jurnal lainnya dan informasi yang tersedia dari berbagai sumber yang telah dipublikasikan ataupun tidak dipublikasikan baik di dalam atau di luar organisasi, yang semuanya mungkin sangat berguna bagi peneliti (Sekaran, 2000:425). Sementara itu, tehnik analisis yang digunakan menggunakan tehnik analisis deskriptif dengan pendekatan kuantitatif.

\section{HASIL DAN PEMBAHASAN}

Berikut rangkuman hasil pengukuran ratarata kinerja Reksadana Saham Syariah selama periode pengamatan tahun 2010- 2014 yang tertuang pada grafik di bawah ini: 


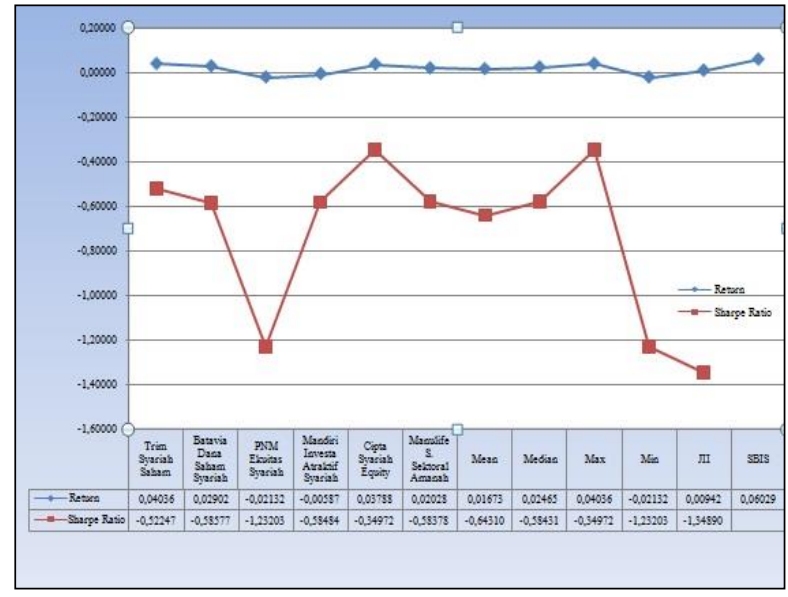

Sumber : Data Diolah

Grafik di atas merupakan rangkuman rata- rata kinerja Reksadana Saham Syariah selama lima tahun pengamatan yang diukur berdasarkan nilai return dan sharpe ratio. Pada enam sampel Reksadana Saham Syariah di atas, terlihat bahwa terdapat dua Reksadana Saham Syariah yang memberikan tingkat pengembalian (return) negatif yakni:

Grafik di atas merupakan rangkuman rata- rata kinerja Reksadana Saham Syariah selama lima tahun pengamatan yang diukur berdasarkan nilai return dan sharpe ratio. Pada enam sampel Reksadana Saham Syariah di atas, terlihat bahwa terdapat dua Reksadana Saham Syariah yang memberikan tingkat pengembalian (return) negatif yakni:

\section{a. Mandiri Investa Atraktif Syariah :} 0,00587

\section{b. PNM Ekuitas Syariah} 0,02132

Sementara itu, empat Reksadana Saham Syariah lainnya memberikan tingkat pengembalian (return) positif yakni:

a. Trim Syariah Saham 0,04036

b. Cipta Syariah Equity 0,03788

c. Batavia Dana Saham Syariah : 0,02902

d. Manulife Syariah Sektoral Amanah $: 0,02028$

Dapat terlihat bahwa diantara keenam sampel penelitian menunjukkan bahwa Reksadana Trim Syariah Saham memiliki rata- rata kinerja berdasarkan perhitungan tingkat return paling tinggi (Max) dibandingkan dengan reksadana saham syariah yang lainnya dengan rata- rata return sebesar 0,04036 atau 4,03\% selama lima tahun. Dapat terlihat pada lampiran bahwa return yang dihasilkan oleh Reksadana Trim Syariah Saham selama lima tahun selalu bernilai positif kecuali pada tahun 2011 di mana return yang dihasilkan bernilai negatif dengan besaran $-0,01728$ atau $-1,72 \%$.

Sementara itu Reksadana PNM Ekuitas Syariah menjadi Reksadana dengan return paling rendah (Min) selama lima tahun tersebut dengan nilai return sebesar $-0,02132$ atau $-2,13 \%$. Selama periode pengamatan, return yang dihasilkan oleh Reksadana PNM Ekuitas Syariah selalu bernilai negatif kecuali pada tahun 2012 yang memiliki nilai return positif. Nilai return terendah yang dialami oleh Reksadana PNM Ekuitas Syariah terjadi pada tahun 2010 dengan nilai return sebesar 0,05676 atau $-5,68 \%$.

Secara keseluruhan rata- rata (Mean) tingkat pengembalian (return) yang dihasilkan dari keenam sampel Reksadana Saham Syariah adalah 0,01673 atau $1,67 \%$. Sementara itu, rata- rata kinerja yang dihasilkan oleh kinerja pasarnya yakni Jakarta Islamic Index (JII) hanya sebesar 0,00942 atau $0,94 \%$. Hal tersebut mengindikasikan bahwa kinerja Reksadana Saham Syariah lebih baik dibandingkan dengan kinerja pasarnya yakni JII karena tingkat return yang dihasilkan melebihi tingkat return pasarnya. Padahal apabila dilihat dalam lampiran bahwa Reksadana Saham Syariah memiliki kinerja lebih baik dari kinerja pasarnya hanya pada tahun 2012 dan 2014 saja dengan nilai rata- 
rata return sebesar $7,37 \%$ dan $2,97 \%$. Sementara pada tahun 2010, 2011, dan 2013 memiliki kinerja di bawah kinerja pasar dengan rata- rata nilai return masing- masing sebesar $0,32 \%,-2,03 \%$ dan $-0,27 \%$. Selain itu, apabila dibandingkan dengan tingkat risk free rate dalam hal ini yang diwakili oleh SBIS menunjukkan bahwa antara Reksadana Saham Syariah maupun kinerja pasarnya (JII), tidak mampu mengungguli risk free rate- nya dengan nilai rata- rata return SBIS sebesar 0,06020 atau $6,02 \%$.

Dalam mengukur kinerja melalui metode Sharpe Ratio, selama periode pengamatan dapat dilihat secara keseluruhan nilai sharpe ratio yang dihasilkan selalu bernilai negatif. Hal tersebut dikarenakan return yang dihasilkan secara keseluruhan tidak mampu menghasilkan return yang lebih tinggi dibandingkan risk free rate-nya. Walaupun demikian, Reksadana yang memiliki kinerja yang baik berdasarkan metode Sharpe Ratio dapat disusun sebagai berikut:

$\begin{array}{lc}\text { a.Cipta Syariah Equity } & :-0,34972 \\ \text { b.Trim Syariah Saham } & :-0,52247\end{array}$

d.Mandiri Investa A.Syariah : $-0,58484$

e. Batavia Dana Saham Syariah: $-0,58577$

f. PNM Ekuitas Syariah : : $-1,23203$

Berdasarkan hasil perangkingan di atas, terlihat bahwa Reksadana yang memiliki kinerja berdasarkan metode Sharpe paling baik dengan nilai rasio sharpe paling tinggi (Max) yakni Reksadana Cipta Syariah Equity, sementara Reksadana dengan nilai rasio sharpe paling rendah (Min) yakni Reksadana PNM Ekuitas Syariah. Secara keseluruhan nilai Sharpe Ratio yang dihasilkan dari keenam sampel tersebut memiliki nilai distribusi tengahnya (Median) sebesar 0,58431 dan nilai rata- rata (Mean) rasio sharpenya sebesar $-0,64310$. Nilai mean dari rasio sharpe ini apabila dibandingkan dengan nilai rasio sharpe pasarnya (JII) yang hanya sebesar $-1,34890$ ternyata mengindikasikan bahwa kinerja Reksadana Saham Syariah juga lebih baik dibandingkan kinerjanya pasarnya yakni Jakarta Islamic Index (JII).

Sementara itu, apabila kita melihat kinerja Reksadana Saham Syariah dari keenam sampel tersebut berdasarkan kinerja per tahunnya, dapat dilihat sebagai berikut di bawah ini:

\section{Grafik Kinerja Reksadana Saham Syariah Berdasarkan Rata- rata Kinerja per Tahunnya}

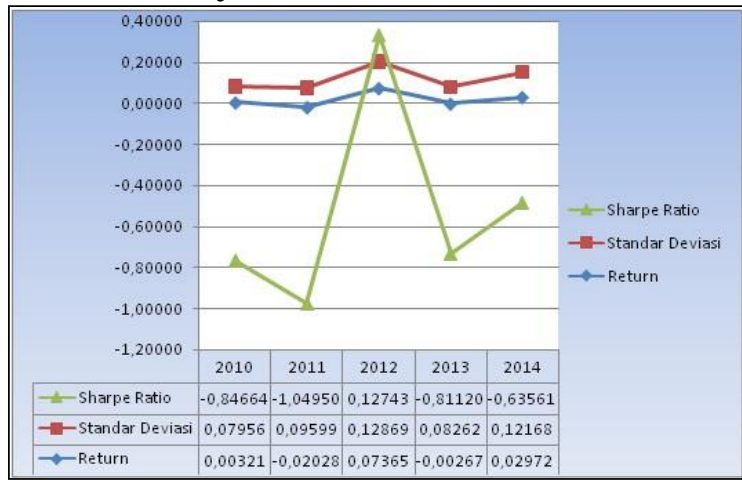

Sumber: Data Hasil Pengolahan

Sementara apabila kita melihat kinerja

Reksadana Saham Syariah berdasarkan ratarata kinerja per tahunnya dapat dilihat pada grafik di atas menunjukkan bahwa berdasarkan tingkat return, Reksadana Saham Syariah memiliki kinerja terbaik berurutan sebagai berikut pada tahun:
a. 2012: 0,07365
b. 2014
: 0,02972
c. 2010: 0,00321
d. 2013
: $-0,00267$

e. $2011:-0,02028$

Pada tahun 2012 menjadi tahun yang sangat menguntungkan bagi Reksadana Saham Syariah karena rata- rata return yang dihasilkan pada tahun tersebut merupakan tingkatan pencapaian return tertinggi sebesar $7,365 \%$ dibandingkan dengan tahun- tahun yang lainnya. Tahun 2012 menjadi tahun yang memiliki return tertinggi karena dari ke enam sampel yang ada semua return yang dihasilkan bernilai positif pada tahun tersebut 
dengan return tertinggi berasal dari Reksadana Batavia Dana Saham Syariah. Sementara tahun 2011 menjadi tahun yang memiliki return terendah karena dari keenam sampel yang ada, lima dari enam sampel tersebut memiliki return negatif dan hanya satu sampel saja yang memiliki return positif pada tahun yang bersangkutan.

Sementara untuk risiko Reksadana Saham Syariah yang diwakili oleh standar deviasinya menunjukkan bahwa susunan risiko mulai dari yang tertinggi sampai dengan risiko yang terendah pada Reksadana Saham Syariah terjadi pada tahun berikut di bawah ini:
a. 2012
: 0,12869
b. 2014
: 0,12168
c. 2011
: 0,09599
d. 2013
: 0,08262
e. 2010
: 0,07956

Sesuai dengan hukum investasi di mana untuk mendapatkan return yang tinggi maka berbanding lurus pula dengan risiko yang dihadapinya (highrisk- highreturn). Hal tersebut juga realitanya terjadi pada Reksadana Saham Syariah di mana tahun 2012 menjadi pencapaian return tertinggi, maka pada tahun 2012 juga menjadi tahun yang memiliki risiko investasi Reksadana Saham Syariah yang tertinggi pula dengan nilai risiko sebesar $12,869 \%$, di mana risiko tertinggi berasal pula dari Reksadana Batavia Dana Saham Syariah (dapat dilihat pada lampiran).

Terkait dengan ukuran kinerja Sharpe Ratio yang merupakan ukuran kinerja berdasarkan return sesuaian risiko menujukkan bahwa susunan Reksadana Saham Syariah yang memiliki kinerja terbaik pada tahun berikut di bawah ini:
a. $2012 \quad: 0,12743$
b. $2014:-0,63561$
c. $2013 \quad:-0,81120$
d. $2010:-0,84664$
e. $2011:-1,04950$

Tahun 2012 menjadi tahun yang memiliki nilai rasio sharpe tertinggi sebesar $12,743 \%$ serta satu- satunya tahun yang memiliki sharpe rasio bernilai positif dikarenakan empat dari keenam sampel bernilai sharpe ratio positif sementara dua sampe yag lainnya bernilai negatif. Hal tersebut menunjukkan pencapain tertinggi kinerja Reksadana Saham Syariah terbaik terjadi pada tahun 2012. Sejalan dengan return, pada sharpe ratio pula kinerja reksadana saham syariah terendah terjadi pada tahun 2011 di mana nilai sharpe ratio yang dihasilkan sebesar $-104,95 \%$.

\section{SIMPULAN}

Berdasarkan hasil penelitian yang telah dijelaskan, peneliti dapat menarik kesimpulan tentang analisis kinerja Reksadana Saham Syariah bahwa Reksadana Cipta Syariah Equity merupakan salah satu Reksadana Saham Syariah yang memiliki kinerja paling baik dibandingkan dengan Reksadana Saham Syariah lainnya dan tahun 2012 menjadi tahun kinerja terbaik Reksadana Saham Syariah

Adapun saran yang diberikan mengenai penelitian ini sebaiknya para investor untuk dapat berpikir bijak mengenai pilihan instrumen pilihannya untuk tidak hanya memperhatikan aspek emosional semata tetapi dengan pertimbangan spiritual dan beberapa anilisis kinerja yang tepat.

\section{DAFTAR PUSTAKA}

Eko Priyono \& Ubaidillah. 2009. Reksadana Solusi

Perencanaan Investasi di Era Modern. Jakarta: PT. Gramedia Pustaka Utama.

Frank J. Fabozzi. 2000. Pasar dan Lembaga Keuangan. Jakarta: Salemba Empat.

Husein Umar. 2008. Metode Penelitian untuk Skripsi dan TesisBisnis. Jakarta: PT Raja Grafindo Persada

Ida Syafrida. 2014. Perbandingan Kinerja Instrumen Investasi Berbasis Syariah dengan Konvensional pada Pasar Modal di Indonesia. Jakarta: Jurnal Al- Iqtishad Vol. VI No.2.

Martalena \& Maya Malinda. 2011. Pengantar Pasar Modal.Yogyakarta: Andi.

Muliaman D. Hadad. (2014). Laporan Triwulan IV OJK. Jakarta: Otoritas Jasa Keuangan. 
Nofie Iman. 2008. Panduan Singkat dan Praktis Memulai Investasi Reksadana. Jakarta: PT. Gramedia.

Sekaran,Uma. 2000. Metode Penelitian untuk Bisnis. Jakarta: Gramedia Pustaka Utama.

Sharpe, William. (1966). Mutual Fund Performance. Journal os Business, vol.39, no.1. (Januari).

Vince Ratnawati \& Ningrum K. (2012). Perbandingan

Reksadana Syariah Kinerja Konvensional. Riau: FE Universitas Riau.

\section{Sumber Internet}

Bareksa. (2014, 02 Desember). Bagaimana Mengukur Kinerja Reksadana dengan Barometer Bareksa. [Online]. Diakses dari http://www.bareksa.com/id/text/201 4/12/02/bagaimana-mengukurkinerja- reksa-dana-denganbarometerbareksa/8595/reksa\%20dana

Faisal Maliki. (2013, Kamis 28 Februauri). Pemenang Penghargaan Reksadana Terbaik 2013. [Online]. Diakses darihttp://www.beritasatu.com/inve stasi- portofolio/99545pemenang-penghargaan-reksadanaterbaik-2013.html 